\title{
A new species of Diplycosia: $D$. benitotanii Argent (Ericaceae) from Mt. Halcon in the Philippines is described in honour of the late Dr. Benito Tan
}

\section{George Argent}

\begin{abstract}
A new species Diplycosia benitotanii (Ericaceae) is described from Mt. Halcon, Mindoro, Philippines in honour of the late Dr. Benito C. Tan. Comments are made on the morphological similarities with other Philippine species in this genus.
\end{abstract}

KEYWORDS: New species, Diplycosia, Ericaceae, Mt. Halcon, Mindoro, Philippines

Diplycosia benitotanii Argent sp. nov. (Fig. 1)

\section{Diagnosis}

Similar to Diplycosia coii Argent but differing in the erect habit (vs. spreading); the mature 'fruit' (i.e. accrescent calyx) being grey not bright blue and this mature calyx completely encloses the ovary unlike the protruding ovary in the mature fruit of $D$. coii. The leaves are slightly larger than those of $D$. coii and the petioles lack the bristles that $D$. coii possesses. The stems have an indumentum only of short white hairs with a few larger brown glandular hairs. In this latter character it also differs from the superficially similar $D$. parvifolia Merr. which has bristles on the petioles and lacks the fine patent pubescence on the stems that $D$. benitotanii displays.

\section{Description}

Erect epiphytic shrub to $c .50 \mathrm{~cm}$ with a tufted habit, new stems arising from the base. Stems brown, splitting and cracking vertically. Young branches pale brown, densely covered in very short patent white hairs and longer (up to 1.25 $\mathrm{mm}$ ) appressed setulose hairs. Leaves spirally arranged along the stems, elliptic, the apex acute with a distinctly protruding gland, the base narrowly to broadly tapering, the under-surface at first with short, brown, sub-appressed glands leaving a punctate surface when these have fallen off, the upper surface smooth, the margin flat, at first with coarse brown appressed hairs (to $c .1 \mathrm{~mm}$ ) which when fallen leave it minutely and obscurely denticulate. The blade $16-28 \times 8-$ $11 \mathrm{~mm}$, the mid-vein slightly impressed both above and

Royal Botanic Garden Edinburgh, Edinburgh, United Kingdom

"Corresponding author: g.argent@rbge.ac.uk

Date Submitted: 26 October 2017

Date Accepted: 23 March 2018 below. One pair of lateral veins faintly visible from above only, arising from near the base, high arching, ascending and variably disappearing from half the length of the leaf to near the apex, sometimes obscure. Petiole grooved, pale green, 2-3 $\times c .1 \mathrm{~mm}$, laxly short, white, hairy and with scattered short brown glandular hairs when young.

Flowers axillary, solitary. Pedicels $c .5 \times 0.5 \mathrm{~mm}$, shortly white hairy and laxly covered with scattered short, brown, appressed, glandular hairs. Bracteoles broadly ovate, obtuse, but apiculate $c .1 .5 \times 1.5 \mathrm{~mm}$, with a few brown glandular hairs, otherwise glabrous except for the brown irregularly fimbriate margin and apiculus. Calyx $c .4 \times 5 \mathrm{~mm}$, limb $2.3 \mathrm{~mm}$, glabrous, the lobes deltoid, $2 \times 1.6 \mathrm{~mm}$, with a short brown glandular margin and tuft of hairs at the apex. Corolla 5-lobed, sub-spherical campanulate, pale green, $5-5.5 \times 4.8 \mathrm{~mm}$, glabrous both outside and within, the lobes reflexed, $1.6 \times 1.9 \mathrm{~mm}$, margin erose. Stamens $10,3.8 \mathrm{~mm}$ long, filaments glabrous, white, anthers brown, $1.4 \mathrm{~mm}$, the cells $0.8 \mathrm{~mm}$, tubules slightly divergent 0.6 $\mathrm{mm}$ opening by oblique pores, both cells and tubules echinulate. Ovary sub-spherical, $1.2 \mathrm{~mm}$ in diameter, glabrous or with one or two long erect hairs, the style, glabrous, green, $3.2 \mathrm{~mm}$. Fruit (with accrescent calyx) $12 \times$ $10 \mathrm{~mm}$ grey, the true capsule forming a hemisphere $c .4 \times$ $5 \mathrm{~mm}$ completely enclosed by the enlarged calyx.

Type: 20091158. Philippines, Mindoro, Oriental Mindoro, Mt. Halcon (c. $13^{\circ} 16^{\prime} \mathrm{N} .120^{\circ} 55^{\prime} \mathrm{E}$.). Original collection: Argent P30a, 15 Mar 1997, Cultivated specimen, grown at the Royal Botanic Garden Edinburgh, collected 8April 2010 (holo $\mathrm{PNH}$, iso $\mathrm{E}, \mathrm{L}$ ). Fig.1.

Etymology. Described in honour of Dr. Benito Tan, popular Philippine botanist of his generation and outstanding bryologist. 


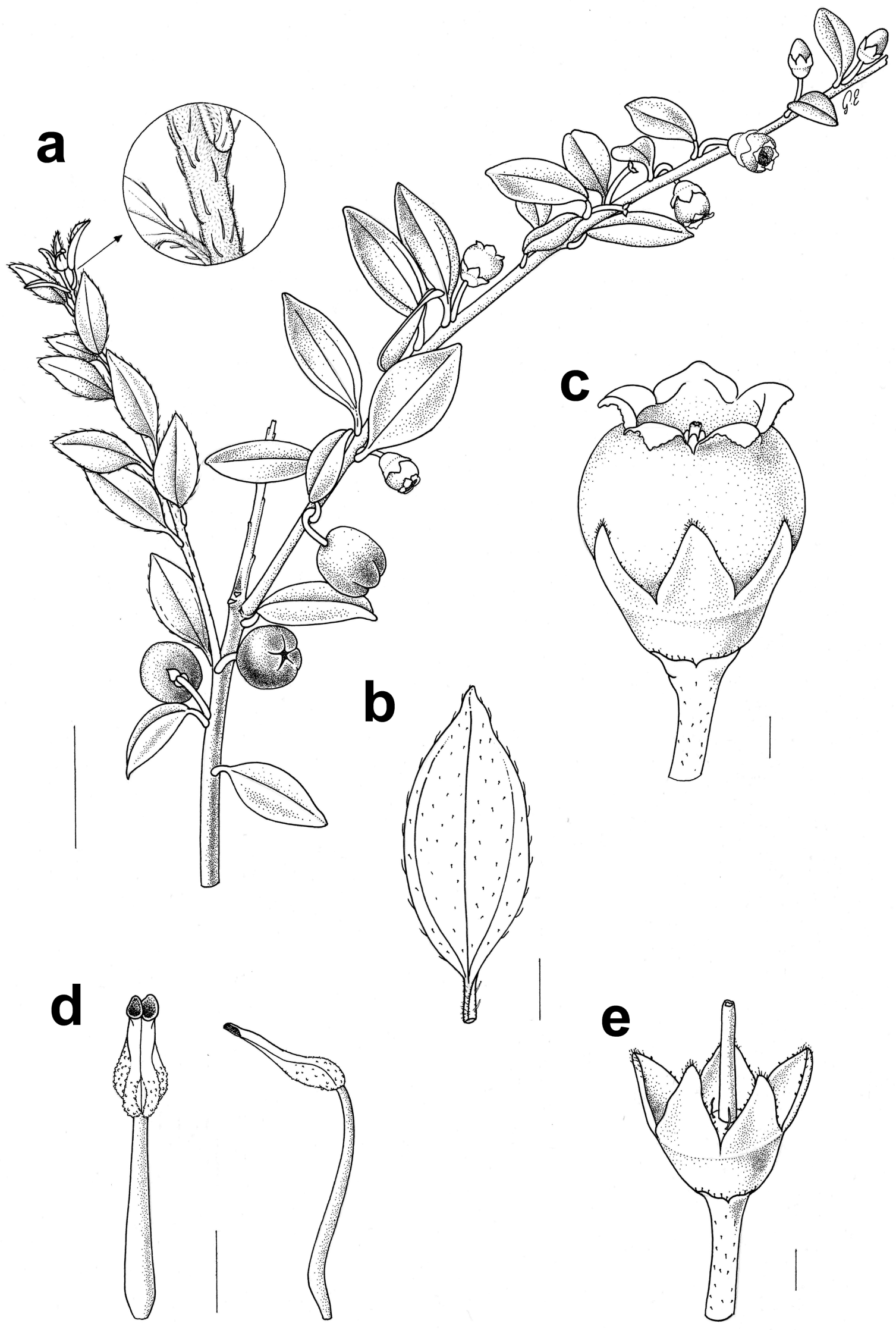

Fig 1. a. Flowering branch with close-up to show indumentum on the stem, scale bar $3 \mathrm{~cm}$; b. Single leaf to show venation, scale bar $5 \mathrm{~mm}$; c. Flower, scale bar $1 \mathrm{~mm}$; d. Stamens, scale bar $1 \mathrm{~mm}$; e. Pistil with calyx, scale bar $1 \mathrm{~mm}$ 
Notes. This new species has been growing in the Royal Botanic Garden Edinburgh, United Kingdom. since it was first collected in 1997 on a joint National Museum of the Philippines, Manila/Royal Botanic Garden, Edinburgh Expedition. It remains an erect shrub becoming densely tufted with innovations arising from the base.

Phenology. Flowering and fruiting throughout the year in cultivation.

Distribution and habitat. Diplycosia benitotanii is known only from Mt. Halcon, Mindoro in the Philippines where it was collected as an epiphyte in sub-montane mossy vegetation at c.2000 m elevation/altitude.

Conservation assessment. Data Deficient. There is no record of the population size of this species. There is still good forest on Mt. Halcon, though not officially declared a protected area which is necessary for the maintenance of the habitat of this epiphytic species.

\section{Discussion}

Since the account of Argent (2013) two new species of Diplycosia have been added to the list of those occurring in the Philippines: D. platyphylla Fritsch (Fritsch \& Amoroso 2016) and D. kitangladensis Fritsch (Fritsch \& Amoroso 2017). Fritsch \& Amoroso (2017) have also reinstated $D$. urdanetensis Elmer, as a good species with convincing arguments demonstrating differences in the indumentum between this species and $D$. trinervia Elmer. $D$. urdanetensis was reduced to a variety of $D$. trinervia by Copeland (1932) and this was followed by Sleumer $(1957,1967)$ in his Flora Malesiana accounts. This present new species brings the total of accepted species for the Philippines to 12. As has been recorded before the species of Diplycosia are noted for their endemicity (Argent 2013, Fritsch \& Amoroso 2017, Sleumer 1957, 1967) and a number of new species are to be expected with further exploration. They are easily overlooked or ignored due to their small, mostly green flowers. The problems of collecting Diplycosia species in good condition for identification have been discussed elsewhere (Argent 1989, 2002, 2013) but it is worth stressing the importance of collecting young growth as well as flowering stems so that the indumentum can be accurately observed before it degrades.

Diplycosia benitotanii keys out in Argent (2013, the most recent key to Philippine Diplycosia) to $D$. coil Argent, also from Mt. Halcon. It differs from that species in the habit which is erect and not spreading; the mature fruit being grey not blue and the accrescent calyx completely enclosing the ovary. These significant characters have been followed and observed over several years in cultivation. The leaf sizes are less significant but in cultivation under the same conditions $D$. benitotanii has leaves which are slightly longer, (up to 28 $\mathrm{mm}$ ) whereas in in $D$. coii they are up to $21 \mathrm{~mm}$ with similar maximum width in both species, thus $D$. benitotanii has slightly more elongate leaves. $D$. coii also has conspicuous bristles on the petioles in addition to the short white patent hairs unlike the present species which although having a similar short white indumentum has only occasional brown hairs on the petioles that appear to be glandular with enlarged apices in contrast to the fine points of the bristles of $D$. coii. $D$. benitotanii is superficially also similar to $D$. parvifolia but this species significantly differs in their lack of the short fine patent pubescence on the stems; the pubescence of the pedicels is also quite different being 'densely appressedly rufous-setulose, with some fine short hairs between the bristles' (Sleumer 1967). It differs from the two most recently described species $D$. platyphylla and $D$. kitangladensis. Both have much larger leaves which are more than $4 \mathrm{~cm}$ long, very prominent lateral venation and lilac or purple calyces on the mature 'fruit'. D. platyphylla additionally differs from the present species in its possession of 3-6 flowered fascicles and D. kitangladensis differs in its strongly urceolate corolla.

The following list is the presently recognized species of Diplycosia in the Philippines. The numbers in brackets refer to the numbered sequence of descriptions in Flora Malesiana (Sleumer 1967).

1. D. apoensis Elmer (40) Leafl. Philipp. Bot. 3: 1101, 1911.

2. D. bartelomei Ferreras \& Argent, Edin. J. Bot. 68 (1): 3942. Fig. 3, 2011.

3. D. benitotanii Argent

4. D. coil Argent Philipp. J. Sci. 142: 51-55, 2013.

5. D. heterophilla Blume var. latifolia (Blume) Sleumer (96) Reinwardtia 4: 156, 1957.

6. D. kitangladensis P.W. Fritsch Nat. Hist. Bull. Siam Soc. 62 (1): 21-27, 2017.

7. D. Ioheri Merr. (11) Philipp. J. Sci. 27: 44, 1925.

8. D. Iuzonica (A. Gray) Merr. (50) Philipp. J. Sci. Bot. 2: 1907.

var. calenanense (Elmer) Sleumer Reinwardtia 4: 144, 1957.

var. merrittii (Merr.) Sleumer Reinwardtia 4: 144, 1957. var. pubens Sleumer Reinwardtia 4: 143, 1957.

9. D. parvifolia Merr. (27) Philipp. J. Sci. 5: 1910.

10. D. platyphylla P.W. Fritsch PhytoKeys 18(69): 31-38. 2016.

11. D. trinervia Elmer (47) Leafl. Philipp. Bot. 3: 1102, 1911.

12. D. urdanetensis Elmer, Leafl. Philipp. Bot. 7: 2628, 1915. 


\section{ACKNOWLEDGMENTS}

I wish to thank Dr. Domingo Madulid of the Philippine National Museum and his staff for supporting the field work during which this species was collected and their valued collaboration over many years. The Royal Botanic Garden, Edinburgh and the Sibbald Trust provided financial support both for the expedition on which this plant was collected and for visits to herbaria at Leiden and Kew to study Philippine Ericaceae. I am grateful to the curators of these herbaria for allowing me to study their specimens. I am indebted to Tony Conlon for his work in successfully cultivating this new species and I am grateful to Gulner Eksi who has skilfully produced the illustration.

\section{LITERATURE CITED}

Argent, G.C.G., 1989. Diplycosia in Borneo. Two new species and a provisional key to Diplycosia and close allies. Notes Royal Botanic Gardens Edinburgh , 46 (1): 17-26.

Argent G.C.G., 2002. New taxa and combinations in the genus Diplycosia (Ericaceae) of Borneo and Peninsular Malaysia. Gardens Bulletin Singapore, 54: 217-238.

Argent G. 2013., A new species of Diplycosia: D. coii Argent (Ericaceae) is described in honour of Leonardo Co. Philippine Journal of Science, 142 (special issue): 51-55.

Copeland H.F., 1932. Philippine Ericaceae III. A taxonomic revision concluded. Philippine Journal of Science, 47: 57115, pls. 1-8.

Fritsch P.W. \& V.B. Amoroso, 2016. Diplycosia platyphylla (Ericaceae), a new species from Mindanao, Philippines. PhytoKeys, 69: 31-38.

Fritsch P.W. \& V.B. Amoroso, 2017. Diplycosia kitangladensis sp. nov. from Mindanao, The Philippines, and taxonomic reassessment of $D$. trinervia. Natural History Bulletin of the Siam Society, 62 (1): 21-27.

Sleumer H., 1957. A revision of the genus Diplycosia (Ericaceae). Florae Malesianae Praecursores XIV. Reinwardtia, 4(2): 119-161.

Sleumer H., 1967. Diplycosia. In: Ericaceae. Flora Malesiana, 6: 469-914. 